\title{
Characteristics of soil respiration in Pinus densiflora stand undergoing secondary succession by fire-induced forest disturbance
}

\author{
Jeong-Seob Kim ${ }^{1}$, Seok-Hwa Lim ${ }^{1}$, Seung Jin Joo², Jae-Kuk Shim ${ }^{3}$ and Keum-Chul Yang ${ }^{1, *}$ \\ ${ }^{1}$ Department of Civil and Environmental Engineering, Kongju National University, Cheonan 330-717, Korea \\ ${ }^{2}$ Center for Atmospheric and Environmental Modeling, Seoul National University, Research Park, Seoul 151-919, Korea \\ ${ }^{3}$ Department of Life Science, Chung-Ang University, Seoul 156-756, Korea
}

\begin{abstract}
The purpose of this study is to compare soil $\mathrm{CO}_{2}$ efflux between burned and unburned sites dominated by Pinus densiflora forest in the Samcheok area where a big forest fire broke out along the east coast in 2000 and to measure soil $\mathrm{CO}_{2}$ efflux and environmental factors between March 2011 and February 2012. Soil $\mathrm{CO}_{2}$ efflux was measured with LI-6400 once a month; the soil temperature at $10 \mathrm{~cm}$ depth, air temperature, and soil moisture contents were measured in continuum. Soil $\mathrm{CO}_{2}$ efflux showed the maximum value in August 2011 as $417.8 \mathrm{mg} \mathrm{CO}_{2} \mathrm{~m}^{-2} \mathrm{~h}^{-1}$ (at burned site) and $1175.1 \mathrm{mg} \mathrm{CO}_{2} \mathrm{~m}^{-2}$ $\mathrm{h}^{-1}$ (at unburned site), while it showed the minimum value as $41.4 \mathrm{mg} \mathrm{CO}_{2} \mathrm{~m}^{-2} \mathrm{~h}^{-1}$ (at burned site) in December 2011 and $42.7 \mathrm{mg} \mathrm{CO}_{2} \mathrm{~m}^{-2} \mathrm{~h}^{-1}$ (at unburned site) in February 2012. The result showed the high correlation between soil $\mathrm{CO}_{2}$ efflux and the seasonal changes in temperature. More specifically, soil temperature showed higher correlation with soil $\mathrm{CO}_{2}$ efflux in the burned site $\left(R^{2}=0.932, P<0.001\right)$ and the unburned site $\left(R^{2}=0.942, P<0.001\right)$ than the air temperature in the burned site $\left(R^{2}=0.668, P<0.01\right)$ and the unburned site $\left(R^{2}=0.729, P<0.001\right) . Q_{10}$ values showed higher sensitivity in the unburned site (4.572) than in the burned site (2.408). The total soil $\mathrm{CO}_{2}$ efflux was obtained with the exponential function between soil $\mathrm{CO}_{2}$ efflux and soil temperature during the research period, and it showed 2.5 times higher in the unburned site $\left(35.59 \mathrm{t} \mathrm{CO}_{2} \mathrm{ha}^{-2} \mathrm{yr}^{-1}, 1 \mathrm{t}=10^{3} \mathrm{~kg}\right)$ than in the burned site $\left(14.69 \mathrm{t} \mathrm{CO}_{2} \mathrm{ha}^{-2} \mathrm{yr}^{-1}\right)$.
\end{abstract}

Key words: $\mathrm{CO}_{2}$ efflux, LI-6400, $Q_{10}$ value, soil temperature

\section{INTRODUCTION}

Although disturbance by logging has been substantially decreased, the forest fire, still as a threatening factor to forest, has been growing in its scale according to increase of forest tree accumulation in these days. Forest of Kangwon-do is accounted for $83 \%$ of the Kangwon-do area and has excellent forest landscape. On the other hand, deforestation area by human interference was more than other province (Lee 1995).
Particularly, large forest fires have intensively occurred in the east coastal region of Korea. The biggest damage occurred in 2000 due to forest fire, simultaneously along east coastal regions (Goseong, Donghae, Kangneung, Samcheok, and Uljin-gun). This accounted for about $0.36 \%$ out of the total forest area of Korea and 80 times larger than that of Yeouido, $2.9 \mathrm{~km}^{2}$ gross area (Choung et al. 2004). The most common vegetation types in the east http://dx.doi.org/10.5141/ecoenv.2014.014

(C) \$ This is an Open Access article distributed under the terms of the Creative Commons Attribution Non-Commercial Licens (http://creativecommons.org/licenses/by-nc/3.0/) which permits unrestricted non-commercial use, distribution, and reproduction in any medium, provided the original work is properly cited.
Received 04 March 2014, Accepted 13 May 2014

*Corresponding Author

E-mail: yangkc@kongju.ac.kr

Tel: +82-41-521-9311 
costal region of Korea are composed of pine tree species containing the high combustible material, so it brings about the widespread forest fire with strong winds of this region. Forest fire is one of the most common disturbance factors in terrestrial ecosystems. It is well known that the frequency and intensity of forest fire influences on large changes in physicochemical properties of forest soils, the species composition of forest vegetation, and various space formation in the forest (Lee et al. 1988). Furthermore, above-ground parts of organisms and organic material is removed by abiotic environmental factors inducing changes (Mun and Choung 1996). Live fuels usually act as a heat sink during combustion until the moisture has been driven out of them: since the moisture content of dead wood is low, combustion of dead fuels drives the moisture out of living fuels (Bond and van Wilgen 1996). The extent and duration of these effects depend firstly upon fire severity, which, in turn, is controlled by several environmental factors that affect the combustion process, such as amount, nature, and moisture of live and dead fuel, air temperature and humidity, wind speed, and topography of the site. Numerous findings on the effects of fire on soil properties are available in the literature (Certini 2005). The damage of forest fire causes changes in forest structure, such as reduction of biomass, and has a fatal effect on the function of ecosystem, such as cycle of material. In addition, the detrimental effects caused by forest fires have been substantially varied physical and chemical properties of forest ecosystems, according to strength and sustainment time of forest fire, moisture content of soil, times when forest fire occurs, and strength of rain after forest fire (Chandler et al. 1983). The forest fire dramatically affects the nutrient cycling and the physical, chemical, and biological properties of the underlying soil (DeBano 1991). However, changes in chemical properties of the soils due to the forest fire are known to be restored to the previous state within two to three years after the oxidation (Woo et al.1985, Lee et al.1988, Woo and Lee 1989). In general, fire-induced changes in most of the soil nutrient cycles are slight and ephemeral except for the nitrogen $(\mathrm{N})$ and phosphorus $(\mathrm{P})$. The availability of these nutrients generally is increased by the combustion of soil organic matter and the increase is strictly dependent upon type of nutrient, burnt tree species, soil properties, and pathway of leaching processes (Kutiel and Shaviv 1992). Also, the fire creates various scales of spaces within the forest according to its scale, and causes change of non-biological environment factors by removing biological entities and organic materials on the ground (Mun and Choung 1996).
As it affects on soil respiration, with organic materials on the ground remove due to this, importance of understandings about the relationship between forest fire and soil respiration has been expanded (Jeong 2007). Soil respiration consists of heterotrophic respiration (mainly by soil microorganism and animals) (Anderson 1982, Landsberg and Gower 1997) and autotrophic respiration (mainly by living plant roots) (Gough and Seiler 2004, Jassal and Black 2006). The process of soil respiration, a procedure of emitting $\mathrm{CO}_{2}$ in the air, which is generated in the oxidization procedure of carbon composites, root respiration of plant, and respiration of soil animal and microorganism, acts as one of major phenomena that emit $\mathrm{CO}_{2}$ from forest ecosystem (Chae et al. 2003). About $10 \%$ of $\mathrm{CO}_{2}$ contained in the air is generated from soil, which accounts for about 10 times larger than emission of $\mathrm{CO}_{2}$ according to consumption of fossil fuel (Raich and Schlesinger 1992). The study of soil respiration has been actively conducted in Korea. Kim (2006) has clarified soil carbon cycle and $\mathrm{CO}_{2}$ emission rate from soil of the Pinus densiflora forest in Sambong Mt. of Hamyang-gun, Kyeongnam, and Lee (2011) has conducted monitoring of the amount of soil respiration in the temperate deciduous forest of Kwangneung. Lee and Mun (2001) have evaluated amount of $\mathrm{CO}_{2}$ annually emitted in the air, soil temperature and soil moisture for soil respiration in the study of soil respiration of the acorn forest, and Moon (2004) has analyzed respiration amount according to the type of trees with comparison in the study of soil respirations of P. densiflora, Quercus variabilis, and Platycarya strobilacea in the region of Jinju, Kyeongnam, and assessed effects of soil temperature and soil moisture for the amount of soil respiration. In addition, Yi (2003) has compared differences among stands by measuring the generation rate of $\mathrm{CO}_{2}$ in soil of Q. variabilis forest in Chuncheon, Kangwon-do, and assessed the annual generation rate of $\mathrm{CO}_{2}$ for each season with figuring out a correlation between soil temperature and soil moisture. However, there has been a lack of studies for a correlation between emission rate of $\mathrm{CO}_{2}$ from soil and impact factors and the annual generation rate of $\mathrm{CO}_{2}$ from soil.

Therefore, this study is intended to conduct a quantitative evaluation of the amount of $\mathrm{CO}_{2}$ generated from soil and to clarify the correlation between impact factors and the annual generation rate of $\mathrm{CO}_{2}$ from soil after going through natural restoration process for 12 years in the region in Samcheok, Kangwon-do, where had been disturbed by forest fire in 2000 . 


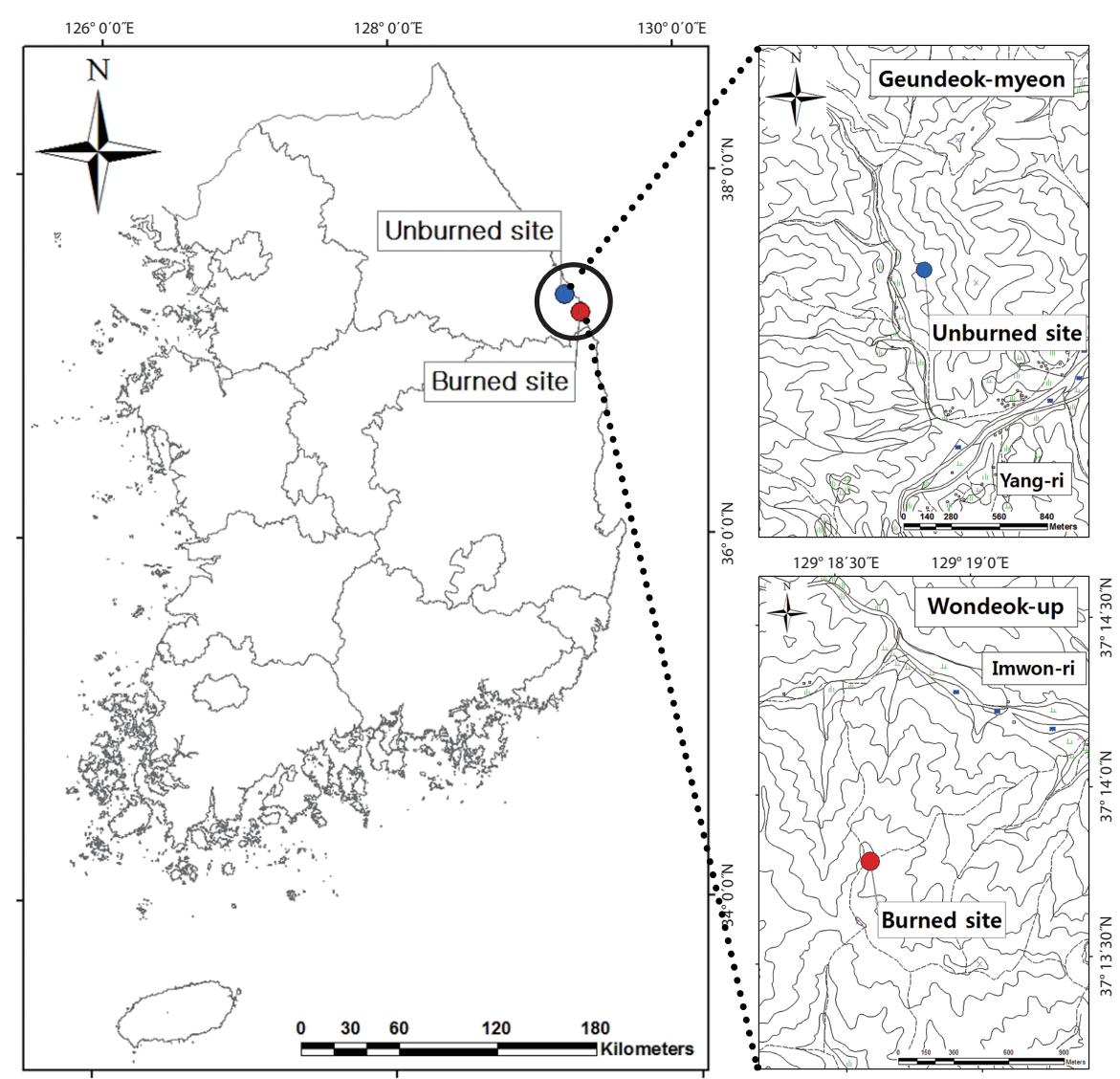

Fig. 1. Map of the study area in Samcheok-si, Gangwon-do (blue dot indicates unburned study site; red dot, burned study site).

\section{MATERIALS AND METHODS}

\section{Study site}

The subject area for this study was located in Samcheok-si, Gangwon-do, with P. densiflora as its major vegetation, where had been widely damaged, equivalent to $70 \%$ out of the total area damaged by forest fire in 2000 , in the east coastal region (Fig. 1). According to the Korea Meteorological Administration (2011) from the Kangwon Regional Meteorological Station, the annual average temperature and the amount of precipitation in this region from March 2011 through February 2012 were $12.4^{\circ} \mathrm{C}$ and $1160 \mathrm{~mm}$, respectively (Fig. 2). Characteristics of vegetation and soil in unburned and burned study sites were shown in Table 1. The permanent quadrat $(20 \mathrm{~m} \times 20 \mathrm{~m})$ in both study sites was installed in 2001. Afterwards, each set of quadrats of $5 \mathrm{~m} \times 5 \mathrm{~m}$ and $10 \mathrm{~m} \times 10 \mathrm{~m}$ was installed in 2007 in the most representative places with homogeneity in the burned site and the unburned study site (Fig. 1). The burned site is a long-term ecological research site designated by Ministry of Environment, in the region of Mt. Geombong where is located in Imwon-ri, Wondeokeup, and where its vegetation was completely burnt by forest fire in 2000 up to crown layer. 12 years had passed since the site was damaged by forest fire, and Quercus mongolica was dominating throughout the shrub layer in there, with some distribution of Quercus serrata and Lespedeza bicolor. The unburned site is located in Dong-

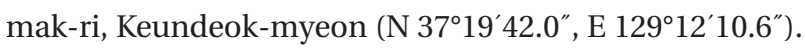
Pinus densiflora was dominating in the tree layer of the unburned site, and diameter at breast height and the height of trees were $26.06 \pm 7.18 \mathrm{~cm}$ and $15.46 \pm 0.47 \mathrm{~m}$ (mean \pm standard deviation), respectively, while Q. serrata and Q. mongolica were dominating with some distribution of Q. variabilis, Castanea crenata, and Rhododendron mucronulatum var. ciliatum.

\section{Method of measuring emission of $\mathrm{CO}_{2}$ from soil}

Small quadrats $(120 \mathrm{~cm} \times 80 \mathrm{~cm})$ were installed in the unburned and burned study sites, and the emission of 
$\mathrm{CO}_{2}$ per unit soil surface area per unit time was measured in the soil by installing each 6 collars with $7 \mathrm{~cm}$ and $5 \mathrm{~cm}$ of height (taking into consideration the height of litter layer at each site) and $10 \mathrm{~cm}$ of diameter (being considered Infrared Gas Analyzer width) inside the quadrats (Fig. 3). The amount of $\mathrm{CO}_{2}$ emitted from the collars was measured once a month at 10 min interval with connecting infrared gas analyzer LI-6400 (Li-Cor Inc., Lincoln, NE, USA) and the closed chamber method (Chae et al. 2003,
Joo et al. 2011) was used to measure soil respiration.

\section{Method of measuring soil temperature and air temperature}

Soil temperature was measured at the soil of $10 \mathrm{~cm}$ depth taking into consideration the forest litter layer (about 3-5 cm in depths). The air temperature at $1.5 \mathrm{~m}$ height was automatically measured at 10 minute interval

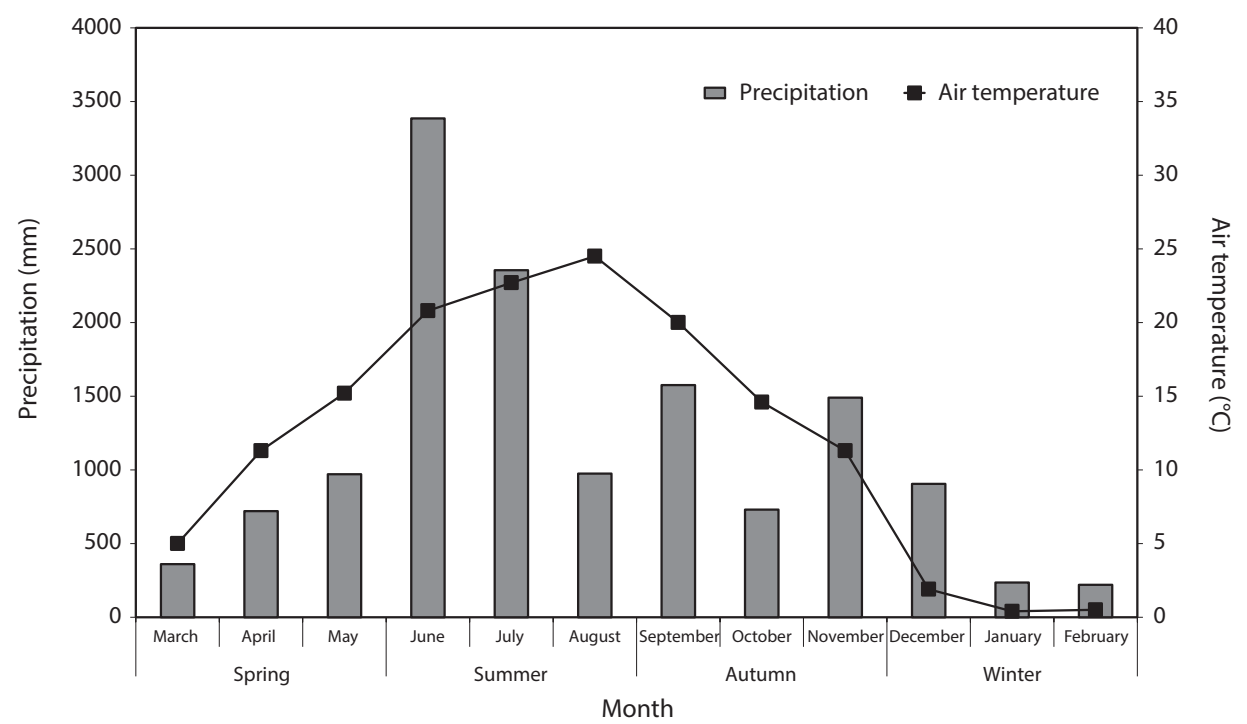

Fig. 2. Seasonal patterns of precipitation and air temperature in the study region from 2011 to 2012.

Table 1. Characteristics of the permanent research plots

\begin{tabular}{|c|c|c|c|c|}
\hline & & & \multicolumn{2}{|c|}{ Study site } \\
\hline & & & Unburned site & Burned site \\
\hline \multirow{8}{*}{ Stand } & & Trees & Pinus densiflora & \\
\hline & Species composition & Shrubs & $\begin{array}{l}\text { Quercus mongilica, } \\
\text { Quercus dentata, } \\
\text { Quercus serrata, } \\
\text { Castanea crenata, } \\
\text { Rhododendron mucronulatum }\end{array}$ & $\begin{array}{l}\text { Quercus mongilica, } \\
\text { Quercus serrata, } \\
\text { Lespedeza bicolor }\end{array}$ \\
\hline & No. of tree $/ 100 \mathrm{~m}^{2}$ & Trees & 10 & \\
\hline & & Shrubs & 39 & 15 \\
\hline & Height (m) & Trees & 15.68 & \\
\hline & & Shrubs & 1.99 & 2.31 \\
\hline & $\mathrm{DBH}(\mathrm{cm})$ & Trees & 26.32 & \\
\hline & & Shrubs & 2.52 & 3.44 \\
\hline \multirow{6}{*}{ Soil } & Total N (\%) & & 0.11 & 0.07 \\
\hline & Total P (mg/g) & & 0.59 & 0.05 \\
\hline & Organic C (mg/kg) & & 0.18 & 0.16 \\
\hline & $\mathrm{Ca}(\mathrm{mg} / \mathrm{g})$ & & 0.77 & 0.94 \\
\hline & $\mathrm{Mg}(\mathrm{mg} / \mathrm{g})$ & & 6.44 & 0.75 \\
\hline & $\mathrm{K}(\mathrm{mg} / \mathrm{g})$ & & 2.43 & 0.22 \\
\hline
\end{tabular}

DBH: diameter at breast height. 


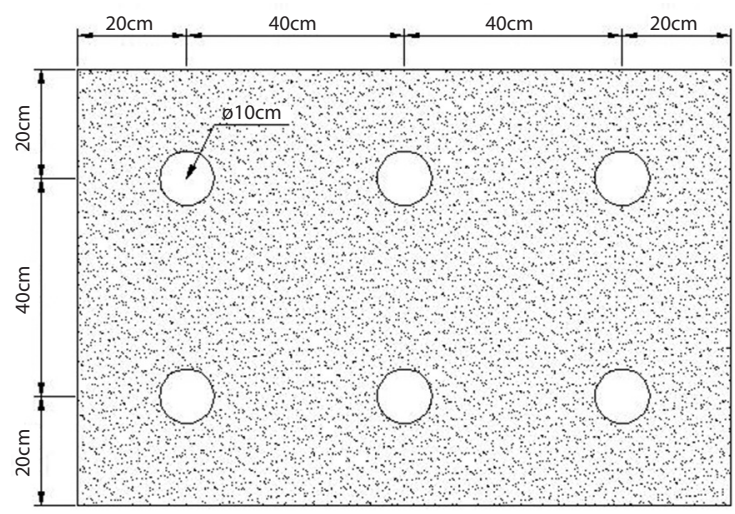

$<$ Floor plan $>$

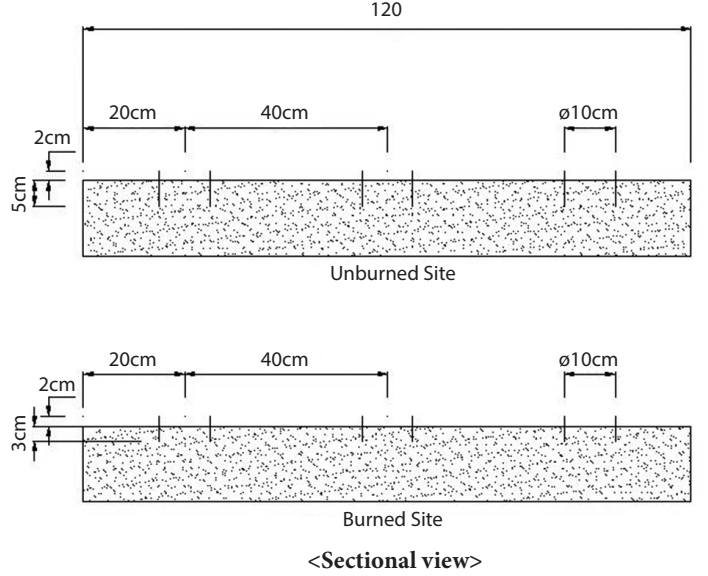

Fig. 3. The installation drawings of collars.

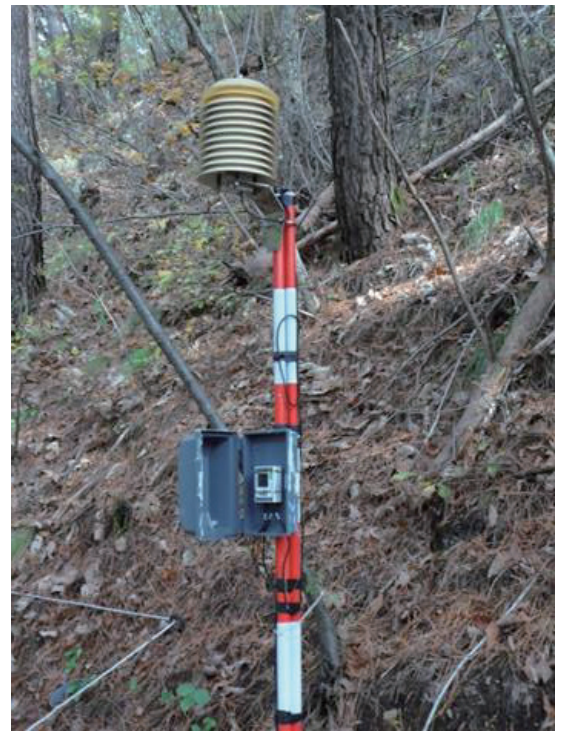

$<$ Unburned Site>

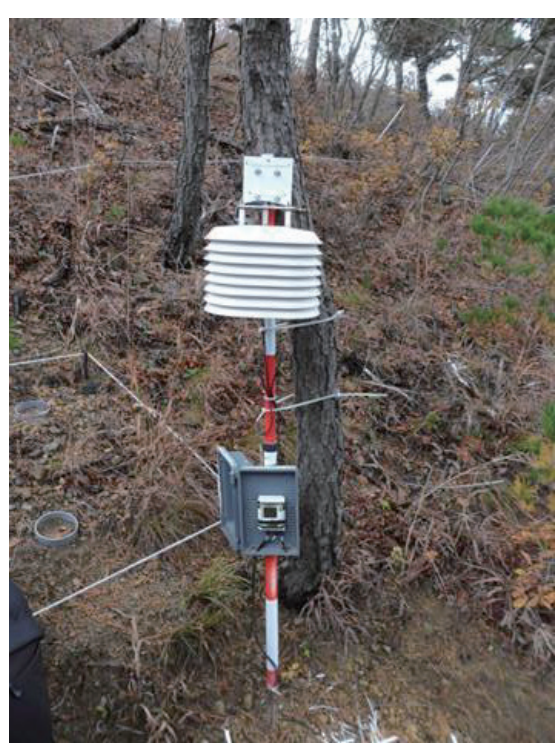

$<$ Burned Site $>$

Fig. 4. The installation photographs of data logger used in this study.

from April 2011 to March 2012 by installing Watch Dog 1000 Series Data Loggers (Spectrum Technologies Inc., Aurora, IL, USA) at each small quadrat in the burned unburned study sites (Fig. 4). The data for Kangwon Regional Meteorological Station (Korea Meteorological Administration 2011) is quoted for the amount of precipitation.

\section{Method of calculating $Q_{10}$ values}

$Q_{10}$ values, the sensitivity of soil respiration to the change of temperature (Fang and Moncrieff 2001), indicate the change of soil respiration and can be assessed by temperature and soil respiration. A large $Q_{10}$ value means that the soil respiration is profoundly changed and sensitive according to the change of temperature. $Q_{10}$ values were calculated with following formula [2], after value of $\mathrm{b}$ was obtained with applying soil respiration rates $\left(R_{\text {soil }}\right)$ and temperature $(T)$ to exponential function [1]:

$$
\begin{aligned}
R_{\text {soil }} & =\mathrm{a} \cdot e^{b T} \\
Q_{10} & =e^{10 b}
\end{aligned}
$$

where $R_{\text {soil }}$ is soil respiration rate $\left(\mathrm{mg} \mathrm{CO}_{2} \mathrm{~m}^{-2} \mathrm{~h}^{-1}\right), T$ is temperature $\left({ }^{\circ} \mathrm{C}\right)$, and $a$ and $b$ are constant. 

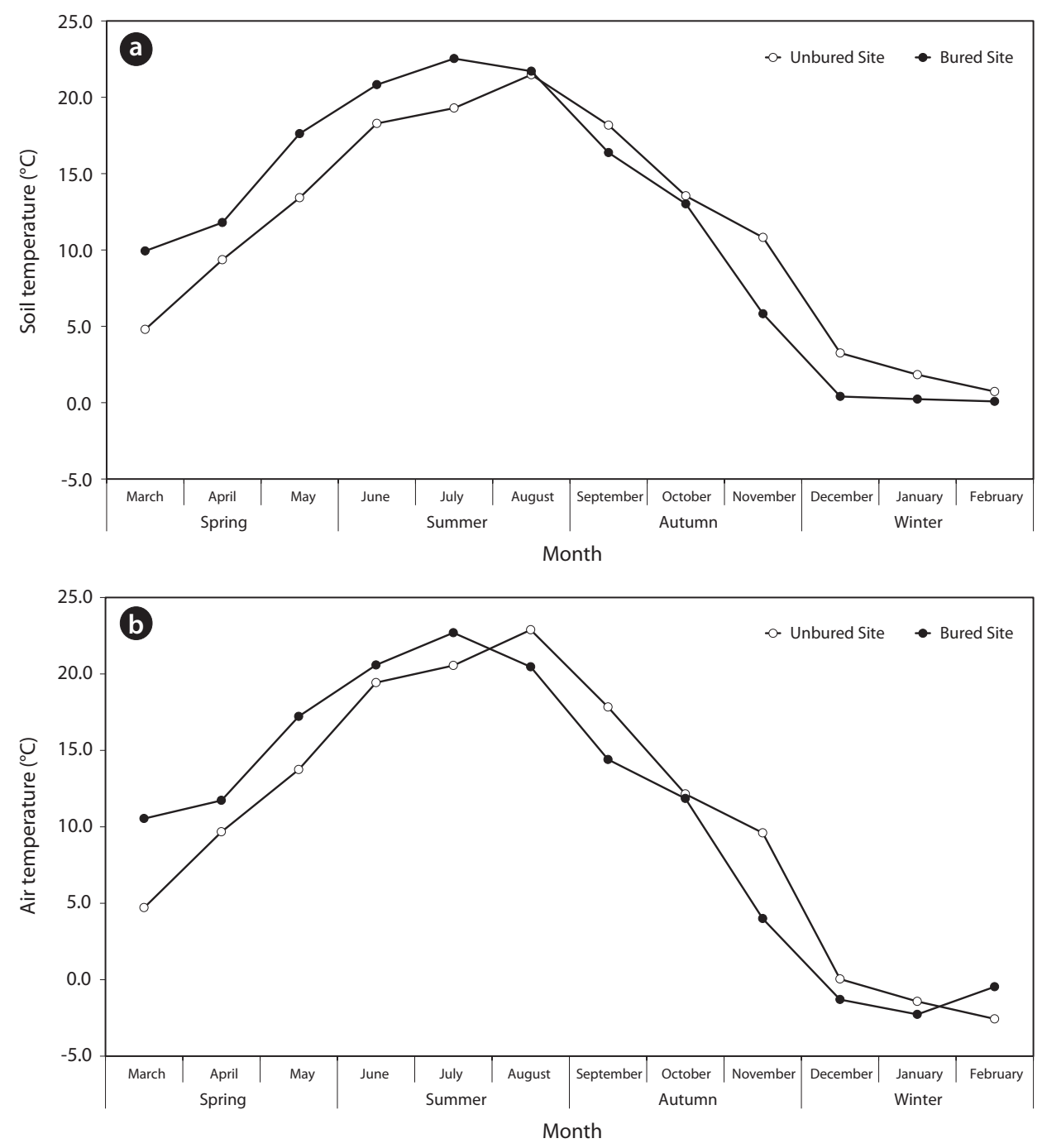

Fig. 5. Seasonal variations of measured monthly mean soil temperature (a) and air temperature (b) in the unburned and burned sites during the study period from March 2011 to February 2012.

\section{Statistical analysis}

For the analysis of correlation between the soil respiration rates and the environmental factors, such as soil temperature, air temperature, content of moisture in soil, and amount of precipitation, regression analysis and ANOVA analysis were conducted with statistical analysis program, SPSS ver. 12.0 (SPSS Inc., Chicago, IL, USA).

\section{RESULTS AND DISCUSSION}

\section{Feature of emission of $\mathrm{CO}_{2}$ from soil in the burned site}

During the entire study period from March 2011 to February 2012, seasonal variations in monthly measured mean soil and air temperature in the unburned and burned sites were shown in Fig. 5. The annual average soil temperature in the unburned site and the burned site for the during the study period were $11.2^{\circ} \mathrm{C}$ and $11.7^{\circ} \mathrm{C}$, respectively. The annual average air temperature in the unburned site and the burned site during the study period were $10.6^{\circ} \mathrm{C}$ and $10.8^{\circ} \mathrm{C}$, respectively.

The emission of $\mathrm{CO}_{2}$ from soil in the burned site ranged from $41.37 \pm 7.78$ to $417.82 \pm 54.98 \mathrm{mg} \mathrm{CO}_{2} \mathrm{~m}^{-2} \mathrm{~h}^{-1}$, while that in the unburned site ranged from $42.66 \pm 6.41$ to $1175.14 \pm 280.03 \mathrm{mg} \mathrm{CO}_{2} \mathrm{~m}^{-2} \mathrm{~h}^{-1}$ (Fig. 6). In both sites, soil respiration decreased after peaking in August (Fig. 6). The annual mean emission of $\mathrm{CO}_{2}$ from soil in the burned site 


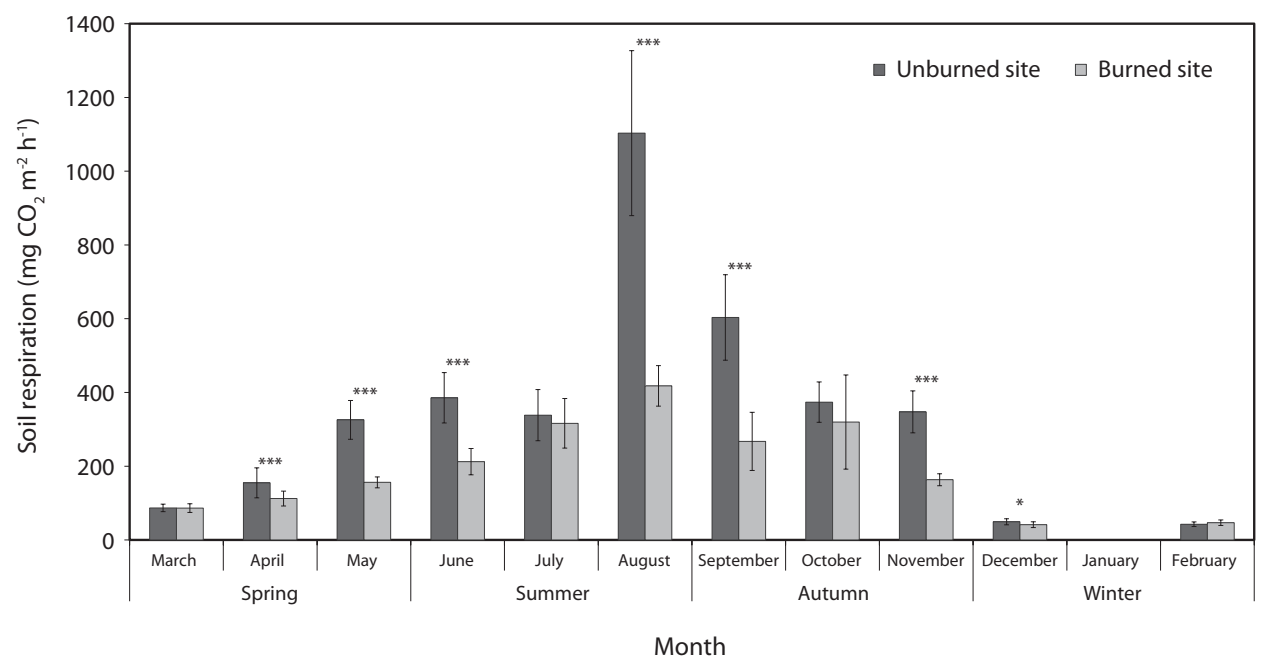

Fig. 6. Seasonal patterns of soil respiration rate for both sites during the study period from March 2011 to February $2012\left({ }^{*}, P<0.05 ;{ }^{* * *}, P<0.001\right)$.
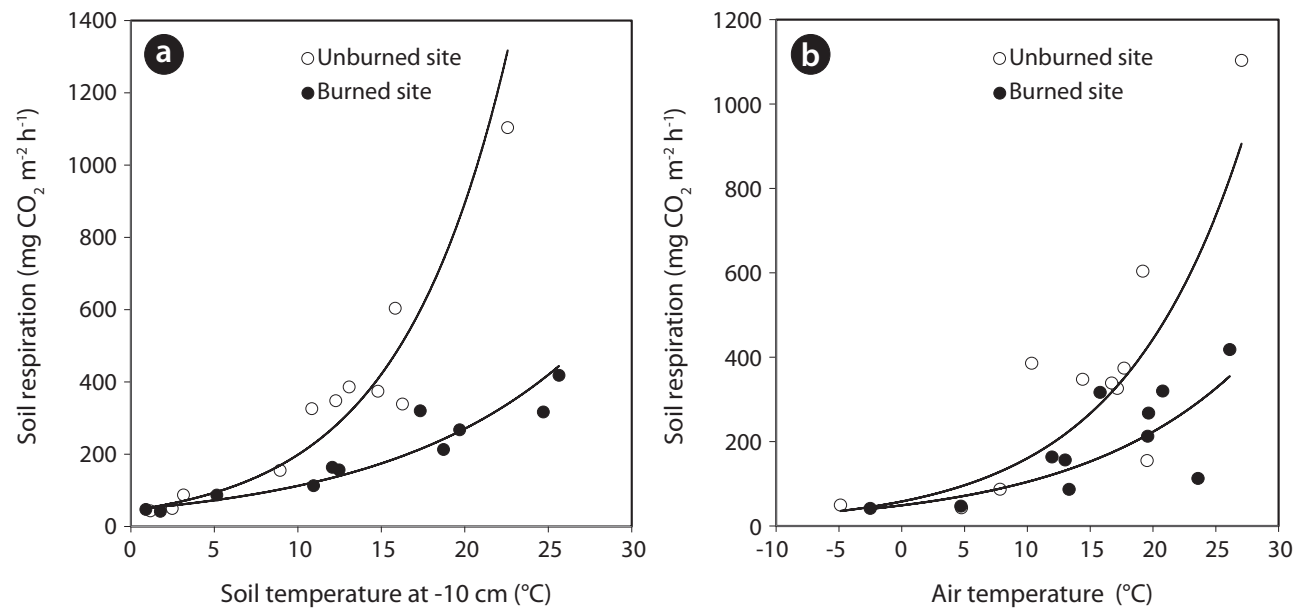

Fig. 7. Relationship between soil respiration and soil temperature (a) and air temperature (b). The white and the black circles represent data from the unburned site and the burned site, respectively.

was $194.51 \pm 123.35 \mathrm{mg} \mathrm{CO}_{2} \mathrm{~m}^{-2} \mathrm{~h}^{-1}$, while it was 353.00 $\pm 322.45 \mathrm{mg} \mathrm{CO}_{2} \mathrm{~m}^{-2} \mathrm{~h}^{-1}$ in the unburned site, indicating about 2 times higher than that in the crown site. With ANOVA analysis of monthly $\mathrm{CO}_{2}$ emission from soil in the unburned site and the burned site, the difference of $\mathrm{CO}_{2}$ emission rate between both sites was statistically significant within $0.1 \%$ in months from April through November, while it was statistically significant around $5 \%$ in December; there was no significance in July and October (Fig. 6). Moon (2004) reported the annual mean soil respiration rate of $430 \mathrm{mg} \mathrm{CO}_{2} \mathrm{~m}^{-2} \mathrm{~h}^{-1}$ at the P. densiflora forest in the region of Jinju, Kyeongnam. In this study, the similar result was obtained in the unburned site consisting of dominant $P$. densiflora forest stand. The amount of soil respiration showed a tendency similar to the result of
Singh and Gupta (1977) indicating that it varied within the range from 10 to $1000 \mathrm{mg} \mathrm{CO}_{2} \mathrm{~m}^{-2} \mathrm{~h}^{-1}$, with being synthesized after measurement in various forest ecosystem of temperate regions.

\section{Effects of environmental factors on $\mathrm{CO}_{2}$ emission from soil}

Correlation between $\mathrm{CO}_{2}$ emission and environmental factors, such as soil temperature, air temperature, and amount of precipitation, was shown in Fig. 7 and Table 2. The relationship between $\mathrm{CO}_{2}$ emission from soil and soil temperature showed a high significance $(P<0.001)$ both in the burned site $\left(R^{2}=0.932\right)$ and the unburned site $\left(R^{2}\right.$ $=0.942$ ), as well as a high positive correlation; however, 
the relationship between $\mathrm{CO}_{2}$ emission from soil and air temperature had a correlation lower than soil temperature both in the burned site $\left(P<0.01, R^{2}=0.668\right)$ and the unburned site $\left(P<0.001, R^{2}=0.729\right)$ (Table 2$)$. This result is identical to the report from a study of soil respiration (Witkamp1966, Son and Kim 1996, McHale et al. 1998, Knapp et al. 1998, Lee and Mun 2001, Yi 2003) demonstrating that soil respiration was led by soil temperature and that there was a high correlation between them. The regression equation induced by real data of soil respiration and soil temperature was used to measure the amount of soil respiration continuously. In this study, the highest soil temperature and the lowest soil temperature were measured once a month, and a high positive correlation between soil respiration and soil temperature were exhibited. $Q_{10}$ values, the sensitivity of soil respiration to the change of soil temperature, are 4.572 and 2.408 in the unburned site and the burned site, respectively, and were more sensitive in the unburned site than in the burned site. These results were higher than the $Q_{10}$ value of 2.38 obtained by Moon (2004) at the P. densiflora forest in the region of Jinju, Kyeongnam. However, in our unburned site, the $Q_{10}$ value was comparable to those of 4.66 and 4.57 obtained by Kim (2008) and Noh et al. (2010), respectively, in the P. densiflora forests. In the burned site, the $Q_{10}$ value was higher than 1.77 after 1 year since forest fire had occurred (Jeong 2007). This value reflected the difference caused by the number of years of forest ecosystem restoration after forest fire. The $Q_{10}$ value was incorporated within the range of 1.3-3.3 for various temperate forest soils in studies of the global $\mathrm{CO}_{2}$ flux reviewed by Raich and Schelesinger (1992), which noticed the relations among the vegetation, climate and soil respiration.

\section{Assessment of annual $\mathrm{CO}_{2}$ emission from soil}

We assessed $\mathrm{CO}_{2}$ emission from soil during the study period in the unburned and burned sites, using a relational expression with soil temperature in the highest correlation with $\mathrm{CO}_{2}$ emission from soil (Table 3). The total $\mathrm{CO}_{2}$ emission from soil $\left(\mathrm{t} \mathrm{CO}_{2} \mathrm{ha}^{-1} \mathrm{yr}^{-1}, 1 \mathrm{t}=10^{3} \mathrm{~kg}\right)$ was 35.59 and 14.69 in the unburned site and the burned site, respectively, during the study period. In the unburned site, the total $\mathrm{CO}_{2}$ emission $\left(\mathrm{t} \mathrm{CO}_{2} \mathrm{ha}^{-1} \mathrm{yr}^{-1}\right)$ was higher than 24.0 in the study of soil respiration in P. densiflora forest in the region of Jinju, Kyeongnam (Moon 2004); 27.32 in the study of soil respiration in P. densiflora forest in Mt. Sambong Hamyang, Kyeongnam (Kim 2006); 21.20 in the study of soil respiration in P. densiflora forest after forest fire (Jeong 2007); and 26.72 in P. densiflora forest in Mt. Mudeung (Kim 2008). However, the obtained annual total soil respiration in various $P$. densiflora forests of Korea was incorporated within the range between 10.0 and 46.0 from the study of Raich and Nadelhoffer (1989). In the burned site, the value was higher than $10.0 \mathrm{t} \mathrm{CO}_{2} \mathrm{ha}^{-1} \mathrm{yr}^{-1}$ after 1 year passed since forest fire in this study, and this

Table 2. Relationships between the soil respiration and temperatures (soil and air) during the study period from March 2011 to February 2012

\begin{tabular}{clccc}
\hline \multicolumn{1}{c}{ Site } & Influence Factor & Equation & $\boldsymbol{R}^{2}$ & $\boldsymbol{Q}_{10}$ \\
\hline Soil temperature & Unburned site & $\mathrm{Y}=43.523 \mathrm{e}^{0.152 \mathrm{x}}$ & 0.942 & 4.527 \\
& Burned site & $\mathrm{Y}=46.665 \mathrm{e}^{0.0879 \mathrm{x}}$ & 0.932 & 2.408 \\
Air temperature & Unburned site & $\mathrm{Y}=57.706 \mathrm{e}^{0.1025 \mathrm{x}}$ & 0.729 & 2.787 \\
& Burned site & $\mathrm{Y}=49.014 \mathrm{e}^{0.0758 \mathrm{x}}$ & 0.668 & 2.134 \\
\hline
\end{tabular}

Table 3. Seasonal and annual soil respiration at the unburned site and burned site during the study period from March 2011 to February 2012

\begin{tabular}{lcc}
\hline & Soil $\mathrm{CO}_{2} \mathrm{Efflux}_{\left(\mathrm{g} \mathrm{CO}_{2} \mathbf{~ m}^{-2} \mathbf{m o n t h}^{-1}\right)}$ & Burned site \\
\hline Season & Unburned site & 257.04 \\
\hline Spring & 452.43 & 687.63 \\
Summer & 2021.66 & 410.79 \\
Autumn & 949.93 & 113.49 \\
Winter & 134.84 & 1468.93 \\
Total $\left(\mathrm{g} \mathrm{CO}_{2} \mathrm{~m}^{-2} \mathrm{yr}^{-1}\right)$ & 3558.88 & 14.69 \\
Total $\left(\mathrm{t} \mathrm{CO}_{2} \mathrm{ha}^{-1} \mathrm{yr}^{-1}\right)$ & 35.59 & \\
\hline
\end{tabular}

"Spring, from March through May; Summer, from June through August; Autumn, from September through November; Winter, from December through February. 
indicated the difference between changes in the forest restoration period after being damaged due to forest fire.

\section{CONCLUSION}

This study was conducted in the P. densiflora forests in the east coastal region of Samcheok-si, Gangwon-do, where went through restoration process for 12 years after burned among the sites with being damaged due to forest fire, to make a quantitative assessment of the correlation between the $\mathrm{CO}_{2}$ emission rates from the soil and environmental factors, and the annual total soil $\mathrm{CO}_{2}$ emission in the damaged sites.

1. The emission of $\mathrm{CO}_{2}$ from soil ranged from $41.37 \pm$ 7.78 to $417.82 \pm 54.98 \mathrm{mg} \mathrm{CO}_{2} \mathrm{~m}^{-2} \mathrm{~h}^{-1}$ in the burned site, and from $42.66 \pm 6.41$ to $1175.14 \pm 280.03 \mathrm{mg} \mathrm{CO}_{2} \mathrm{~m}^{-2} \mathrm{~h}^{-1}$ in the unburned site. It decreased after peaking in August in both sites.

2. The relationship between $\mathrm{CO}_{2}$ emission from soil and soil temperature showed a high significance $(P<0.001)$, as well as a high positive correlation, in both of the burned site $\left(R^{2}=0.932\right)$ and the unburned site $\left(R^{2}=0.942\right)$. However, the relationship between $\mathrm{CO}_{2}$ emission from soil and air temperature was less correlative than that from soil temperature in both of the burned site $\left(P<0.01, R^{2}=\right.$ $0.668)$ and the unburned site $\left(P<0.01, R^{2}=0.729\right)$.

3. The total $\mathrm{CO}_{2}$ emission from soil ( $\left.\mathrm{CO}_{2} \mathrm{ha}^{-1} \mathrm{yr}^{-1}\right)$ was 35.59 and 14.69 in the unburned site and the burned site, respectively, during the study period.

4. In 2012, our burned site was not completely recovered from loss of soil organic matter and nutrient elements, and the vegetation structure undergoing secondary succession had been changed from the pine forest to the oak forest. Even after 12 years passed since forest fire, the vegetation regeneration was so slow that there was the difference in soil respiration between the burned and unburned sites.

5. The annual $\mathrm{CO}_{2}$ emission from soil in this study was assessed by the correlation between the environmental factors during the 1 year. In further studies, the long-term and continuous measurement of $\mathrm{CO}_{2}$ emission from soil should be necessary to assess it in accuracy. In addition, the studies of restoration method for $\mathrm{CO}_{2}$ reduction are also be needed, by assessing the amount of $\mathrm{CO}_{2}$ storage and emission from soil in the process of restoring vegetation after being damaged by forest fire, and by measuring $\mathrm{CO}_{2}$ emission from soil in the initial stage after forest fire occurred.

\section{LITERATURE CITED}

Anderson JPE. 1982. Soil respiration. In: Methods of Soil Analysis, Part 2: Chemical and Microbiological properties (Page AL, Miller RH, Keeney DR, eds). American Society of Agronomy, Medison, WI, pp 831-871.

Bond WJ, van Wilgen BW. 1996. Fire and Plants. Chapman \& Hall, London.

Certini G. 2005. Effects of fire on properties of forest soils: a review. Oecologia 143: 1-10.

Chae NY, Kim J, Kim DG, Lee DW, Kim RH, Ban JY, Son YH. 2003. Measurement of soil $\mathrm{CO}_{2}$ efflux using a closed dynamic chamber system. Kor J Agr Forest Meteorol 5: 94100.

Chandler C, Cheney P, Thomas P, Trabaud L, Williams D. 1983. Fire in Forestry, Vol. I: Forest Fire Behavior and Effects. Wiley, New York, NY.

Choung Y, Lee BC, Cho JH, Lee KS, Jang IS, Kim SH, Hong SK, Jung HC, Choung HL. 2004. Forest responses to the large-scale east coast fires in Korea. Ecol Res 19: 43-54.

DeBano LF. 1991. The effect of fire on soil properties - Proceedings- management and productivity of western montane forest soil. In: Proceedings of Management and Productivity of Western-Montane Forest Soils, Boise, ID, April 10-12, pp 151-156.

Fang C, Moncrieff JB. 2001. The dependence of soil $\mathrm{CO}_{2}$ efflux on temperature. Soil Biol Biochem 33: 155-165.

Gough CM, Seiler JR. 2004. The influence environmental, soil carbon, root, and stand characteristics on soil $\mathrm{CO}_{2}$ efflux in loblolly pine (Pinus taeda L.) plantations located on the South Carolina coastal plain. For Ecol Manage 191: 353-363.

Jassal RS, Black TA. 2006. Estimating heterotrophic and autotrophic soil respiration using small-area trenched plot technique: theory and practice. Agr Forest Meteorol 140: 193-202.

Jeong MJ. 2007. Soil respiration and soil microbial activity after fire in a Pinus densiflora stand. MS Thesis. Kangwon University, Chuncheon, Korea. (in Korean with English abstract)

Joo SJ, Park MS, Kim GS, Lee CS. 2011. $\mathrm{CO}_{2}$ flux in a cooltemperate deciduous forest (Quercus mongolica) of Mt. Nam in Seoul, Korea. J Ecol Field Biol 34: 95-106.

Kim C. 2006. Soil carbon cycling and soil $\mathrm{CO}_{2}$ efflux in a Red Pine(Pinus densiflora)stand. J Ecol Field Biol 29: 23-27.

Kim SB. 2008. Soil $\mathrm{CO}_{2}$ efflux and leaf-litter decomposition in Pinus densiflora and Quercus variabilis stand. MS Thesis. Chonnam University, Gwangju, Korea. (in Korean with English abstract)

Knapp AK, Conard SL, Blair JL. 1998. Determinants of soil 
$\mathrm{CO}_{2}$ flux from a sub-humid grassland: effect of fire and fire history. Ecol Appl 8: 760-770.

Korea Meteorological Administration. 2011. Weather Resources Database. http://www.kma.go.kr/. Accessed from March 2011 to February 2012.

Kutiel P, Shaviv A. 1992. Effects of soil type, plant composition and leaching on soil nutrients following a simulated forest fire. For Ecol Manage 53: 329-343.

Landsberg JJ, Gower ST. 1997. Application of Physiological Ecology to Forest Management. Academic Press, New York, NY.

Lee JS. 2011. Monitoring soil respiration using an automatic operating chamber in a Gwangneung temperate deciduous forest. J Ecol Field Biol 34: 411-423.

Lee KS. 1995. Mechanisms of vegetation succession on abandoned fields after shifting cultivation in Chinbu, Kangwon-Do. PhD Dissertation. Seoul National University, Seoul, Korea.

Lee WK, Choi K, Oh MY. 1988. Effect of forest fire on soil properties and vegetation. Res Rep For Res Kor 37: 3549. (in Korean with English summary)

Lee YY, Mun HT. 2001. A study on the soil respiration in a Quercus acutissima forest. Korean J Ecol 24: 141-147. (in Korean with English abstract)

McHale PJ, Mitchell MJ, Bowles FP. 1998. Soil warming in a northern hardwood forest: trace gas fluxes and leaf litter decomposition. Can J For Res 28: 1365-1372.

Moon HS. 2004. Soil respiration on Pinus densiflora, Quercus variabilis and Platycarya strobilacea stands in Jinju, Gyeongnam Province. Korean J Ecol 27: 87-92. (in Ko- rean)

Mun HT, Choung YS. 1996. Effects of forest fire on soil nutrients in pine forests in Kosong, Kangwon Province. Korean J Ecol 19: 375-383. (in Korean with English abstract)

Noh NJ, Son YH, Lee SK, Jo WY, Lee NY, Bae SW, Kim HS. 2010. Diurnal pattern of soil $\mathrm{CO}_{2}$ efflux in a Pinus densiflora forest measured using an open-flow chamber system. Forest Sci Technol 6: 41-45.

Raich JW, Nadelhoffer KJ. 1989. Belowground carbon allocation in forest ecosystems: global trends. Ecology 49: 471-483.

Raich JW, Schlesinger WH. 1992. The global carbon dioxide flux in soil respiration and its relationship to vegetation and climate. Tellus B 44: 81-99.

Singh JS, Gupta SR. 1977. Plant decomposition and soil respiration in terrestrial ecosystems. Bot Rev 43: 449-528.

Son YH, Kim HW. 1996. Soil respiration in Pinus rigida and Larix leptolepis plantation. J Korean For Soc 85: 496-505. (in Korean with English abstract)

Witkamp M. 1966. Rates of carbon dioxide evolution from the forest floor. Ecology 47: 492-494.

Woo BM, Kwon TH, Ma HS, Lee HH, Lee JH. 1985. Effects of forest fire in the forest vegetation and soil (II). Jour Korean For Soc 68: 37-45. (in Korean with English abstract)

Woo BM, Lee HH. 1989. Effects of forest fire in the forest vegetation and soil (IV). Jour Korean For Soc 78: 302-313.

Yi MJ. 2003. Soil $\mathrm{CO}_{2}$ evolution in Quercus variabilis and Q. mongolica forests in Chunchon, Kangwon Province. J Korean For Soc 92: 263-269. 